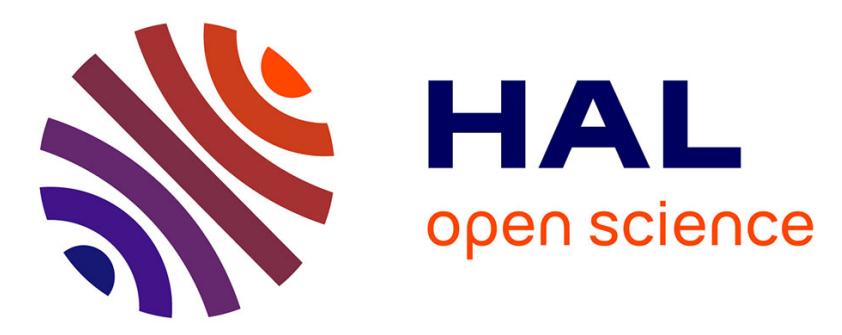

\title{
Short-term effect of beach replenishment on a shallow meadow
}

\author{
José M. González-Correa, Yolanda Fernández-Torquemada, José Luis \\ Sánchez-Lizaso
}

\section{> To cite this version:}

José M. González-Correa, Yolanda Fernández-Torquemada, José Luis Sánchez-Lizaso. Short-term effect of beach replenishment on a shallow meadow. Marine Environmental Research, 2009, 68 (3), pp.143. 10.1016/j.marenvres.2009.06.002 . hal-00499563

\section{HAL Id: hal-00499563 https://hal.science/hal-00499563}

Submitted on 10 Jul 2010

HAL is a multi-disciplinary open access archive for the deposit and dissemination of scientific research documents, whether they are published or not. The documents may come from teaching and research institutions in France or abroad, or from public or private research centers.
L'archive ouverte pluridisciplinaire HAL, est destinée au dépôt et à la diffusion de documents scientifiques de niveau recherche, publiés ou non, émanant des établissements d'enseignement et de recherche français ou étrangers, des laboratoires publics ou privés. 


\section{Accepted Manuscript}

Short-term effect of beach replenishment on a shallow Posidonia oceanica meadow

José M. González-Correa, Yolanda Fernández-Torquemada, José Luis SánchezLizaso

PII:

S0141-1136(09)00063-4

DOI: 10.1016/j.marenvres.2009.06.002

Reference:

MERE 3340

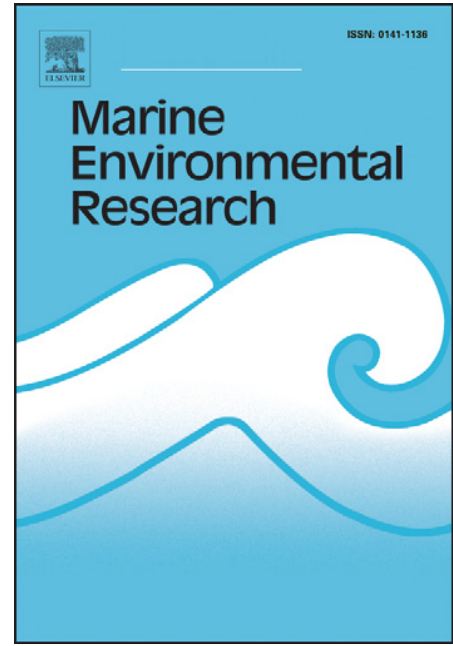

To appear in:

Marine Environmental Research

Received Date:

8 February 2009

Revised Date:

28 May 2009

Accepted Date:

1 June 2009

Please cite this article as: González-Correa, J.M., Fernández-Torquemada, Y., Sánchez-Lizaso, J.L., Short-term effect of beach replenishment on a shallow Posidonia oceanica meadow, Marine Environmental Research (2009), doi: 10.1016/j.marenvres.2009.06.002

This is a PDF file of an unedited manuscript that has been accepted for publication. As a service to our customers we are providing this early version of the manuscript. The manuscript will undergo copyediting, typesetting, and review of the resulting proof before it is published in its final form. Please note that during the production process errors may be discovered which could affect the content, and all legal disclaimers that apply to the journal pertain. 
Short-term effect of beach replenishment on a shallow Posidonia oceanica meadow.

José M. González-Correa ${ }^{1,2 *}$,

Yolanda Fernández-Torquemada ${ }^{2}$, José Luis Sánchez-Lizaso².

${ }^{1}$ Centro de Investigación Marina de Santa Pola, CIMAR, Ayto. de Santa Pola y Univ. de Alicante. Torre d'Enmig s/n, Cabo de Santa Pola, Alicante, Spain.

${ }^{2}$ Departamento de Ciencias del mar y Biología Aplicada, Universidad de Alicante. POB 99, E-03080-Alicante, Spain.

FAX number: +34 965909897

*Corresponding author. e-mail address: jmiguel.gonzalez@ua.es 
Abstract

Putative perturbations on a $P$. oceanica meadow produced by recent artificial beach nourishment were evaluated in relation to four undisturbed meadows. Temporal variations of putative impacted location versus control locations of environmental (light availability and sediment features), plant (associated epiphytes, silt-clay fraction attached to epiphytes, herbivore attack, non-structural carbohydrate reserves) and structural parameters (cover and density) of meadows were tested by asymmetrical analysis of variance beyond BACI (Before/After, Control/Impact). Additionally, two asymmetrical analyses of variance were used to test for differences in vegetative growth of horizontal rhizomes (leaf production, horizontal rhizome growth, biomass production and net secondary rhizome recruitment) before and after beach replenishment. Environmental effects induced by dumping works were only detected in connection with a higher silt-clay deposition rate. This increase was consistent with the increase of silt-clay cover attached to epiphytes. As a consequence of silt-clay smothering, a decrease of filter feeding epiphytes, starch reserves, shoot surface and shoot biomass was observed. The sensitivity of plants to sediment inputs, leads us to recommend avoidance of dumping or sediment movement in the vicinity of $P$. oceanica meadows.

Keywords: beach replenishment, short-term impact, earlier impact, Posidonia oceanica

Introduction.

Nowadays beach nourishment is widely considered as a better alternative for coastal protection than the construction of hard structures to mitigate detrimental erosive effects 
(Hamm et al., 2002; Hanson et al., 2002). However, despite the fact that from an engineering viewpoint it is considered as an "environmental-friendly" option for coastal protection (Miller et al., 2002), sizeable impacts on several beach ecosystem components (microphytobenthos, vascular plants, terrestrial arthropods, marine zoobenthos, and avifauna) are described in the literature (Peterson et al., 2000; Rumbold et al., 2001; Peterson et al., 2006; Speybroeck et al., 2006; Colosio et al., 2007).

In the Mediterranean Sea, the endemic seagrass Posidonia oceanica constitutes a key component, which provides valuable ecological goods and services for shallow water ecosystems (Terrados and Borum, 2004). P. oceanica beds cover large areas, spreading from locations near the shoreline to depths of 50-60 meters. When they are established close to sandy beaches they play an important role in the sand budget and shoreline protection. This occurs through: a) enhancement of sedimentation and decantation of suspended particles into the water column and its subsequent retention (Terrados and Duarte, 2000; Gacía and Duarte, 2001), b) reduction of the erosive energy of waves (Gambi et al., 1989; Gacía and Duarte, 2001), c) nourishment of beaches with calcareous parts of organisms that live in them (Falco et al., 2000), and finally d) protection of beaches against erosion through the accumulation on the shoreline of leaves lost annually (Boudouresque and Jeudy de Grissac,1983).

$P$. oceanica is adapted to the natural sediment mobility of sandy bottoms by vertical growth of rhizomes to avoid burial (Boudouresque and Jeudy de Grissac, 1983). Nevertheless, beach replenishments involve large inputs of sediments in the short-term causing potentially dramatic environmental changes that can overcome response 
mechanisms. Burial is the most obvious detrimental effect on the plant. Manzanera et al. (1998) demonstrated in a manipulative experiment that $100 \%$ of rhizomes died after burial to a depth of $15 \mathrm{~cm}$ for 200-300 days. In addition, siltation leads to an increase in the turbidity and organic matter load (Malmer and Grip, 1994), both of which negatively affect seagrass growth (Giesen et al., 1990; Sand Jensen and Borum, 1991). Sediments with a high silt-clay fraction can limit seagrass photosynthesis by reflecting and absorbing available light (Onuf, 1994; Abal and Dennison, 1996; Longstaff and Dennison, 1999; Ruíz and Romero, 2003) or by enhancing epiphyte growth on leaves promoted by nutrient input associated with exogenous sediment (Neverauskas, 1987; Cebrian et al., 1999).

As a consequence of these effects, a wide range of $P$. oceanica meadow responses to sediment input are described in the literature, including: 1) no effect, as a result of a well planned and managed project (Borg et al., 2006; Ebejer, 2004); 2) a pulse disturbance (Guidetti, 2001); and 3) the regression of meadows (Astier, 1984; Birzebbuga's case reported in Borg et al., 2006) where surviving plants are continuously submitted to a long-term press disturbance (González-Correa et al., 2008).

P. oceanica is a resilient plant, and as such it is expected to show first a slight responses in the short-term following the impact, which will lead to more serious symptoms (including death) if the cause of the impact persists. Long-term effects of beach replenishment on $P$. oceanica have been identified previously (González-Correa et al., 2008), but early symptoms linked to short-term effects are unknown. 
Here, our goal was to identify early warning symptoms of $P$. oceanica as a consequence of stress of artificial beach nourishment. We hypothesized that short-term environmental changes (light availability and sediment features) related to the input of sediment may have a negative impact on the vitality of meadows. Both the accumulation of sediment on seafloor and the increase of silt-clay fraction into water column are environmental consequences expected from dumping. If burial occurs, with significant changes in the height sediment on the seafloor, then structural changes could be detected in meadows in short-term, such as changes in density and cover. If only siltclay fraction suspended into water column reach the meadow, then a subtle cascade of effects could be trigged. Early effects may begin with the decrease of the light available and the filter feeding epiphytes and increases in the silt-clay deposition rate, the silt-clay fraction attached to epiphytes, the epiphyte load and herbivore attack. These changes could lead to modifications in the non-structural carbohydrate content (decreasing starch and soluble carbohydrates) and in vegetative growth (slowing the growth of leaves and rhizomes). This first symptoms may subsequently be followed by structural changes in meadows, such as changes in density and cover.

\section{Material and methods.}

2.1 Study area and sampling design.

The study was carried on between 2004 and 2006 on the upper depth limit of a $P$. oceanica meadow spread along nine kilometres of the northern Alicante shoreline (SE Spain, SW Mediterranean Sea). In this area, the shoreline has retreated due to touristrelated beach management practices and building, including the systematic elimination of the protective remainds of $P$. oceanica leaves from the shoreline and the dune plant 
communities. In order to counteract the ensuing erosion, a replenishment project was carried out on Deveses beach from July 2005 to June 2006. Sand was trucked from a nearby quarry and dumped along a $1300 \mathrm{~m}$ stretch of beach. It was observed that sediments were eroded and the beach outline reached a new equilibrium slope. As a consequence, coarse sediment particles will be transported only short distances from their origin, while small particles (silt-clay) can be suspended for longer periods and move farther, potentially reaching on the nearby $P$. oceanica meadows. Therefore, we randomly chose a putative impacted location off Deveses beach (the only replenished beach in the area; hereafter impacted location: (I)) and four control locations (hereafter; $\mathrm{C} 1, \mathrm{C} 2, \mathrm{C} 3$ and $\mathrm{C} 4)$. We replicated control locations in order to describe the natural variability of $P$. oceanica meadows in the area. Understanding natural variability is critical to assess how impacted locations vary from controls (Kingsford and Battershill, 1998). The impacted location was placed $440 \mathrm{~m}$ from the dumping location at the upper depth limit of the meadow. We assumed that this was the closest point to the dumping site for beach replenishment and that it would therefore be the most sensitive. Control locations were placed distant enough from the planned dumping to prevent any negative effects. They were spaced between 1000 to 3000 m apart. Locations depths ranged from 5 to $6 \mathrm{~m}$ (Fig 1). Light, sediment and plant parameters were sampled before beach replenishment (June 2005) and one year after. Sediments dumped on the shoreline were sampled on three occasions during dumping work (in July 2005, November 2005 and June 2006).

\subsection{Environmental variables.}

\subsubsection{Sediments}


For sediment characterization, two $4 \times 10 \mathrm{~cm}$ cores were taken at each location and at the dumping area. The upper $10 \mathrm{~cm}$ portion of each core was used to estimate the organic matter and silt-clay concentrations $(<0.063 \mathrm{~mm})$. Sediment was dried for $24 \mathrm{~h}$, weighed and sifted through a five sieve column $(2,0.5,0.25,0.125$ and $0.063 \mathrm{~mm}$; sifter CISA model RP-03). The fraction smaller than $63 \mu \mathrm{m}$ was estimated by subtracting initial dry weight from final dry weight of sediment retained on sieves (Buchanan, 1984). Loss-On-Ignition (LOI) was used to estimate the organic matter content in the sediments following the method of Luczak et al. (1997). Water content was determined at $105^{\circ} \mathrm{C}$. Thereafter, the oven-dried samples were heated in a furnace at $500^{\circ} \mathrm{C}$ for $6 \mathrm{hr}$. The samples were cooled in a dessicator before measurement.

In order to measure annual variations in sediment height, we drove twelve labelled sticks (80 cm long) into the sea floor (approximately half of the stick) at each location. The distance from the top of each labelled stick to the sea floor was measured in July of 2004, 2005 and 2006. Sticks were placed $1 \mathrm{~m}$ apart each other.

The silt-clay deposition rate $\left(\mathrm{mg} \mathrm{DW} \mathrm{m} \mathrm{m}^{-2} \mathrm{~d}^{-1}\right.$ ) was evaluated by installing two sediment traps (diameter $8.5 \mathrm{~cm}$, height $28 \mathrm{~cm}$ ) on seafloor at each location for a period of 20 days in June 2006. They were closed before the sediment traps were withdrawn. In the laboratory, they were vigorously shaken and three sub-samples of $200 \mathrm{ml}$ were subsequently taken from each sediment trap. Each sub-sample was filtered first by a 63 $\mu \mathrm{m}$ sieve (sifter CISA model RP-03) and later re-filtered through a $0.7 \mu \mathrm{m}$ glass microfiber filter disc (Whatman type GF/F). We obtained the weight of sediment retained by subtracting the total dry weight of the $0.7 \mu \mathrm{m}$ filter and the sediment 
retained (dried for at least $1 \mathrm{hr}$ at $103-115^{\circ} \mathrm{C}$ ) from the initial dry weight of the filter. The methodology applied followed the ESS Method 340.2 (1993).

\subsubsection{Light conditions}

To assess light conditions at each locality, light intensity (lux) was measured in situ using photometer loggers (ONSET Stow Away LI) with an accuracy of \pm 0.01 lux. Photometers were placed at canopy level by attaching them to sticks pushed vertically into sediment in empty spaces in the meadow. Light measurements were continuously recorded each 15 min from 07.00 to 20.00 GMT for a 14 day period each year (in June 2005 and 2006), which we considered short enough to prevent shading effects by

fouling. Photometrics units (lux) were converted to quantum units ( $\mu \mathrm{mol}$ PAR m $\mathrm{m}^{-2} \mathrm{~s}^{-1}$ ) applying the experimental algorithm

$$
\log Y\left(\mu \text { mol PAR m }{ }^{-2} s^{-1}\right)=(0.9828 x \log X(\operatorname{lux}))-0.038 \text {. }
$$

This algorihtm was calculated through an experimental regression in Gonzalez-Correa (2008).

\subsection{Plant variables.}

P. oceanica meadow structure was surveyed at each location by estimating density and cover of living and dead plant material. Shoot density was estimated by counting living shoots in three random $40 \times 40 \mathrm{~cm}$ quadrats per location. Living and dead $P$. oceanica cover were estimated as the proportion of living and dead $P$. oceanica patches on three replicated $25 \mathrm{~m}$ transects at each location. 
To estimate leaf, epiphyte variables and non-structural carbohydrate content, 10 vertical shoots were harvested in each location 'before' and 'after' dumping. Shoot surface $\left(\mathrm{cm}^{2}\right.$ $\operatorname{shoot}^{-1}$ ), shoot biomass (g DW shoot $^{-1}$ ) and epiphyte biomass per leaf surface unit (mg DW $\mathrm{cm}^{-2}$ ) were estimated following the method described for these parameters in Ruíz and Romero (2001). Damage by herbivore attack was estimated calculating the percentage of bitten leaves at each shoot (\% bitten leaves).

Cover of epiphytes and filter feeding epiphytes, and the cover of silt-clay attached to epiphytes were estimated by 15 randomly distributed 5 x $5 \mathrm{~mm}$ quadrats. Each of five quadrats were allocated to young, medium and old leaves. We used a binocular microscope and a sampling square printed on a transparent plastic sheet subdivided into smaller squares of $1 \mathrm{~mm}^{2}$ in order to enhance the accuracy of the method.

Non-structural carbohydrates were estimated by cutting the first $3 \mathrm{~cm}$ from the apical part of the rhizomes to obtain samples. Samples were dried $\left(100^{\circ} \mathrm{C}\right.$ for $\left.24 \mathrm{~h}\right)$ and converted into powder. Rhizome powder was heated with ethanol $\left(80^{\circ} \mathrm{C}, 15 \mathrm{~min}\right.$ in the Heating Block), centrifuged (3000 rpm, $10 \mathrm{~min})$ and finally the supernatant was separated from insoluble residues in different tubes. Soluble carbohydrates were extracted from the supernatant by evaporating ethanol and dissolving the residues in deionised water for further analysis. Starch was extracted from insoluble residues by keeping it for $24 \mathrm{~h}$ in $\mathrm{NaOH}(0.1 \mathrm{~N})$. Soluble carbohydrates and starch content of extracts were determined spectrophotometrically using anthrone assay, with sucrose as a standard (Yemm and Willis, 1954). 
To evaluate vegetative growth, 10 principal horizontal rhizomes separated by 1-2 m, were labelled at the apex at each location before dumping. They were identified and pulled out one year later, removing the longest portion of horizontal rhizome possible. Since the distance from the label to the apex can be considered to represent growth of 1 yr, we directly obtained annual vegetative growth estimates by measurement. The total age of each horizontal rhizome was estimated by the lepidochronology technique (Pergent, 1990). This technique is based on the thickness cycle of sheaths attached to rhizomes; identifying an annual period which equates to the length of rhizome as measured between two sheaths of minimum thickness. Minimum thickness sheaths are obvious in vertical but not in horizontal rhizomes. Hence, the age of a horizontal piece of rhizome was calculated as the age expressed by subtracting the youngest from the oldest vertical rhizome to which it was connected. This dating method was not sensitive to horizontal rhizomes younger than 1 yr; therefore, only rhizomes older than $3 \mathrm{yr}$ were selected in order to minimize such imprecision (González-Correa et al 2005).

Both methods (direct and indirect) allowed us to obtain annual estimates of the following seagrass variables: leaf production of horizontal rhizomes (leaves $\mathrm{y}^{-1}$ ), estimated by counting sheaths; horizontal rhizome growth, which was obtained by measuring its length following rhizome contour; biomass production of horizontal rhizomes $\left(\mathrm{g} \mathrm{DW}^{-1}\right)$, estimated after drying rhizomes for $24 \mathrm{~h}$ at $80^{\circ} \mathrm{C}$; and net production of secondary rhizomes (new secondary rhizomes $\mathrm{y}^{-1}$ ), calculated as the difference between branches which formed and those that died per year. While it is possible to distinguish between secondary, tertiary and quaternary shoots (Molenaar et $a l ., 2000)$, we focused on secondary rhizomes because they are the only ones that are likely to branch on the one-year-old horizontal rhizome fraction. 
2.4 Data analyses.

To test differences in environmental parameters (sediment features and light availability), epiphyte features, phenological parameters, carbohydrate reserves, and structural parameters (cover and density) and examine temporal differences between the potentially impacted location and the randomly-selected control locations, we used a "beyond BACI" (Before/After, Control/Impact) asymmetrical analyses of variance. The "beyond BACI" design employs various controls in order to avoid problems of spatial confounding (or "pseudoreplication"; Hurlbert, 1984). A new level of spatial replication was not considered necessary because of the relatively short stretch of shoreline replenished (approximately $1300 \mathrm{~m}$ ) during the study period versus the longer stretch of impacted location (approximately 40-50 m, similar to controls). The mechanics and the logical structure of these analyses are fully explained by Underwood (1992, 1993, 1994).

To test vegetative growth variables of horizontal rhizomes, two separate asymmetrical analyses of variance for each time (before/after) were used. The change in analysis with respect to the above variables was necessary because vegetative growth variables emanate from different methods. The 'before' dumping values were obtained by an indirect method and represent the average of various previous years, while 'after' dumping values were obtained by a direct method and only represent the value of a year (the impact period). We tested if vegetative growth of horizontal rhizomes at the impacted location was significantly different with respect to those from control locations, before and after sediment dumping, but without temporal interaction. The 
mechanics and the logical structure of asymmetrical analyses of variance are fully explained in Glasby et al. (1997). Finally, to test for differences in silt-clay deposition in the last year, we used an asymmetrical analysis of variance. Before analysis, Cochran's test was used to test for homogeneity of variance for all variables. Where significant differences were found, the data were $\ln (x+1)$ transformed.

\section{Results}

\subsection{Environmental parameters.}

Grain size analyses of dumped sediment on the shoreline revealed a low content of both silt-clay $(<2.5 \%)$ and organic matter fraction $(<1 \%)$ at each of the three sampling times (Fig. 2). Consequently, dumped sediment volume was not sufficient to provoke a significant variation of sediment height at the impacted location. Sediment height ranged approximately $\pm 2 \mathrm{~cm}$ for each annual period measured, which was similar to the values recorded at the control locations (Fig. 3.1). The silt-clay fraction and organic matter at the impacted location did not differ significantly from the control locations either before or after dumping (Fig 3.2, 3.3). We detected a large silt-clay and organic matter fraction in C1, which came from the nearby Racons creek (see Fig. 1). However, the silt-clay deposition rate was significantly higher at the impacted location after dumping in comparison to the controls, including $\mathrm{C} 1\left(181 \mathrm{mg} \mathrm{DW} \mathrm{m}^{-2} \mathrm{~d}^{-1}\right.$ at impacted location vs $75 \mathrm{mg} \mathrm{DW} \mathrm{m} \mathrm{d}^{-1}$ average of controls; Fig 3.4). Finally, light availability at the impacted location did not differ significantly either before or after dumping compared to the control locations (Fig 4).

\subsection{Plant variables.}


Shoot surface and biomass at the impacted location decreased from before to after dumping (shoot surface: $199.7 \pm 12.8 \mathrm{~cm}^{2} \operatorname{shoot}^{-1}$ to $109.8 \pm 7.6 \mathrm{~cm}^{2}$ shoot $^{-1}$; shoot biomass: $1.005 \pm 0.007$ to $0.735 \pm 0.008 \mathrm{~g} \mathrm{DW}$ shoot $^{-1}$; Fig 5). Whereas, shoot surface and shoot biomass at control locations did not show significant interactions in relation to dumping time. Herbivorous attack did not differ before and after dumping at control locations ( $p>0.05)$ and was always highly variable (28.3 to $54 \%$ of bitten leaves). In contrast, herbivory was always high at the impacted location $(59.5$ to $59.6 \%$ of bitten leaves), therefore no significant changes in herbivory in impacted location were detected ( $\mathrm{p}>0.05)$. Dumping provoked increased epiphyte biomass, an increased load of silt-clay attached to epiphytes and decreased the cover of filter feeding epiphytes at the impacted location, while in controls, no significant differences were detected (Fig. 6). Epiphyte cover was not affected $(\mathrm{p}>0.05)$, which indicated that although weight increased, as a consequence of silt-clay attached to epiphytes, the area of settled surface did not.

After dumping, starch reserves of rhizomes at the impacted location dropped to half of the levels measured in 2005 (from $29.7 \pm 4.9$ to $13.0 \pm 1.2 \mathrm{mg}$ starch g DW rhizome ${ }^{-1}$ ), while values at control locations remained within a similar range (Fig. 7.1). Significant variability in soluble carbohydrate concentration occurred at control locations in relation to time $(\mathrm{p}<0.05)$, which prevented the decreasing trend at the impacted location from being significantly detected (Fig. 7.2).

Vegetative growth of horizontal rhizomes at the impacted location was similar for leaf production, net production of secondary rhizomes and biomass production compared to 
the controls before and after dumping. Horizontal rhizome growth at impacted location was significantly lower the year after dumping. However this difference may be better explained by an increase of $\mathrm{C} 3$ location than by a significant decrease in impacted location (Fig 8)

Finally, no significant changes were detected in structural parameters (shoot density and cover of alive and dead P.oceanica) in impacted location as a consequence of dumping $(\mathrm{p}>0.05)$.

\section{Discussion}

This beach replenishment was characterised by the small amount of sediments dumped with a very low silt-clay fraction $(<2.5 \%)$. Sediments eroded from the dumping area reached the meadows increasing silt-clay deposition rate and the silt-clay cover attached to epiphytes, but it was not enough to provoke any measurable changes to sediment features on seafloor (sediment level, silt-clay fraction and organic matter) or to light availability at the impacted location.. The increase in silt-clay deposition rate was consistent with the diminishing of cover of filter feeding epiphytes. It should be noted that differences observed are due to the high proportion of filter feeding epiphytes before the dumping in comparison with controls. Filtration mechanisms of epiphytes become clogged if the silt-clay fraction in the water column is high, and this is known to interfere with ingestion and respiration (McFarland and Peddicord, 1980; Waters, 1995; Ellis et al., 2002), which subsequently leads to changes in the distribution of epibenthic species (Cohen et al., 2000, Lohrer et al., 2006). Due to the high temporal and spatial 
variability of epiphytes, further studies should be performed in order to confirm this trend.

P. oceanica starch reserves at the impacted site is higher than at control sites before dumping and decreased by half after the beach replenishment. This fall is consistent with the reduction in shoot surface and biomass of leaves. Before dumping, leaves were longer in impacted location than controls locations. Since sampling was simultaneous at all locations differences in shoot surface, shoot biomass and starch reserves before the dumping are not related with seasonality and may indicate a higher vitality of the plants of the impacted locality before the beach replenishment. After dumping sampling (same week one year later), similar features on leaves and starch level would indicate that vitality of plants was similar in all locations. The reduction of vitality of the plants after the dumping in the impacted location is consistent with the increase of epiphyte biomass and the increase of silt-clay attached to epiphytes. It could involve a lengthy smothering effect, which may affect the carbon budget of the plant, although no decrease in light availability was detected at the time of sampling. Reserves depletion could occur in two possible ways: a) clogging the pass of nutrients and bicarbonates necessary for plant development or b) preventing the normal transfer of light through the leaf epidermis.

In any case these results should be interpreted with caution since it should be better to have sampled several times before the impact to be sure that this meadow had a higher vitality in relation to the meadows used as controls.

Soluble carbohydrates showed a highly variable behaviour at controls both before and after dumping, preventing the decrease at the impacted location from being statistically significant. The variable behaviour of soluble carbohydrates matches the results of a previous study (González-Correa et al., 2008) and could be explained by the fast 
response of soluble carbohydrates to growth status (Touchette and Burkholder, 2000) and photosynthethic problems (Ruíz et al., 2001).

No effect was observed on the vegetative growth of rhizomes. This result contrasts with the $45 \%$ reduction of net total rhizome recruitment determined by a long-term effect of beach replenishment study on shallow P. oceanica meadows (González-Correa et al., 2008). Discrepancies between the results can be explained by the different sets of environmental conditions that affected the health of plants in the two studies. In the long-term effect study, beach replenishment was undertaken using marine sediments and affected two sheltered meadows which retained a high silt-clay and organic matter fraction in the sediment $18 \mathrm{yr}$ after dumping took place. In contrast, the more exposed impacted meadow in the present study was characterized by a low silt-clay and organic fraction in the sediment. In addition, different volumes of sediment were dumped on the beaches used in the two studies (personal observation).

Natural processes may increase sediment inputs on the meadows. It is well known that $P$. oceanica is not present in front of important rivers that produce a continuous input of sediments. In our study one of the controls is placed in front of a gully that is usually dry except after periods of heavy rainfall which in the Mediterranean climate may be separated by decades. The high amount of silt-clay in the $\mathrm{C} 1$ location may be related to historical sediment inputs, although this kind of event was not observed during our study period. This increase in the silt-clay fraction in the meadow sediment seems not to affect the plant features. This result indicates that the organic matter load of the sediments is more relevant than the silt-clay content to explain the low recruitment after the beach replenishment with marine sediments (González-Correa et al., 2008). While 
in that study the amount of organic matter of the impacted locations ranged between 15 and $20 \%$, in this study it was lower than $4 \%$ at all locations.

\section{Conclusions}

In conclusion, the small inputs of sediments into the water column due to sediment dumping for beach replenishment provoked the increase of the sedimentation rate and the sediments attached to the seagrass leaves but it was not sufficient to produce measurable changes in light availability or sediment level. Early warning symptoms of response of $P$. oceanica, such as starch depletion, shoot size reduction, and changes in epiphytes may be related to the smothering effects on leaves. Further studies on the smothering effects on leaves are necessary to determine if the impacts observed in the short-term produce a negative carbon budget that in turn results in regression of the meadow in the long-term. The sensitivity of plants to small sediment inputs, leads us to recommend avoiding undertaking work that involves dumping or sediment movement in the vicinity of $P$. oceanica meadows.

\section{Aknowledgements}

Thanks are due Tim Dempster for improving an earlier version of the manuscript and two anonymous referees by their constructive criticisms.

\section{References}

Abal, E.G., Dennison, W.C., 1996. Seagrass depth range and water quality in southern Moreton Bay, Queesland, Australia. Marine and Freshwater Research 47, 763-771. 
Astier, J.M., 1984. Impacts des aménagements littoraux de la rade de Toulon, liès aux techniques d'endigage, sur ler herbiers à Posidonia oceanica, in: Boudouresque, C.F., Jeudy de Grissac, A., Olivier, J. (Eds), International Workshop on Posidonia oceanica beds. GIS Posidonie Publ., Marseille, pp 255-259.

Alcoverro, T., Manzanera, M., Romero, J. 2001. Annual metabolic carbon balance of the seagrass Posidonia oceanica: the importance of carbohydrates reserves. Marine Ecology Progress Series 211, 105-116.

Borg, J.A., Gauci, M.J., Magro, M., Micallef, M.A., 2006. Environmental Monitoring at St George's Bay (Malta) in connection with Beach Replenishment Works, in: Proceedings of the 2nd International Conference on the Management of Coastal Recreational Resources Beaches, Yacht Marinas and Coastal Ecotourism, Gozo, Malta, pp. 25-33.

Boudouresque, C.F., Jeudy de Grissac, A., 1983. Posidonia oceanica in the Mediterranean: interactions between the plant and the sediment. Journal de Recherche Oceanographique 8, 99-122.

Buchanan, J.B., 1984. Sediment analyses. In: Holme, N.A.; McIntyre, A.D. (Eds), Methods for the study of marine benthos ( $2^{\text {nd }}$ edition). Blackwell, Oxford, pp 41-65.

Cebrian, J., Enríquez, S., Fortes, M., Agawin, N., Vermat, J.E., Duarte, C.M., 1999. Epiphyte accrual on Posidonia oceanica (L.) Delile leaves: implications for light absorption. Botanica Marina 42, 35-43.

Cohen, B.F., Currie, D.R., McArthur, M.A., 2000. Epibenthic community structure in port Philip Bay, Victoria, Australia. Marine and Freshwater Research 51, 689-702.

Colosio, F., Abbiati, M., Airoldi, L., 2007. Effects of beach nourishment on sediments and benthic assemblages. Marine Pollution Bulletin 54, 1197-1206.

Ebejer, J., 2004. Creating a sandy beach in St George's Bay-a new experience for Malta, in: Proceedings of the first international conference on the management of 
coastal and recreational resources, beaches, yacht marinas and coastal ecotourism, University of Malta, Malta, pp. 161-167.

Ellis, J.I., Cummings, V., Hewitt, J., Thrush, S., Norkko, A., 2002. Determining effects of suspended sediment on condition of a suspension feeding bivalve (Atrina zelandica): results of a survey, a laboratory experiment and a field transplant experiment. Journal of Experimental Marine Biology and Ecology 267, 147-174

ESS Method 340.2: Total suspended solids, mass balance (Dried at 103-105 ${ }^{\circ} \mathrm{C}$ ). Volatile suspended solids (Ignited at $550{ }^{\circ} \mathrm{C}$ ). 1993. Winconsin state lab of hygiene, Madison, WI 53706. Available at:www.epa.gov/glnpo/lmmb/methods/methd340.pdf

Falco, G., Ferrari, S., Cancemi, G., Baroli, M., 2000. Relationship between sediment distribution and Posidonia oceanica seagrass. Geo-Marine Letters 20, 50-57

Gacía, E., Duarte, C.M., 2001. Sediment retention by a Mediterranean Posidonia oceanica meadow: the balance between deposition and resuspension. Estuarine Coastal Shelf Science 52, 505-514.

Gambi, M.C., Buia, M.C., Casola, E., Scardi, M., 1989. Estimates of water movement in Posidonia oceanica beds: a first approach, in: Boudouresque, C.F., Meinesz, A., Fresi, E., Gravez, V. (Eds.), International Workshop on Posidonia Beds, vol. II., GIS Posidonie Publ., Marseille, pp. 101-112.

Glasby, T.M., 1997. Analysing data from post-impact studies using asymmetrical analyses of variance: A case study of epibiota on marinas. Australian Journal of Ecology 22, 448-459.

Giesen, W.B.T., Katwijk, J., Hartog, C., 1990. Eelgrass condition and turbidity in the Dutch Wadden Sea. Aquatic Botany 37, 71-85.

González-Correa, J.M., Bayle, J.T., Sánchez-Lizaso, J.L., Valle, C., Sánchez-Jerez, P., Ruiz, J.M. 2005. Recovery of deep Posidonia oceanica meadows degraded by trawling. Journal of Experimental Marine Biology and Ecology 320, 65-76. 
González-Correa, J.M., Fernández-Torquemada, Y., Sánchez-Lizaso, J.L., 2008. Longterm effect of beach replenishment on natural recovery of shallow Posidonia oceanica meadows. Estuarine Coastal Shelf Science 76, 834-844.

Guidetti, P., 2001. Detecting environmental impacts on the Mediterranean seagrass Posidonia oceanica (L.) Delile: the use of reconstructive methods in combination with "beyond BACI" designs. Journal of Experimental of Marine Biology and Ecology 260, 27-39.

Hamm, L., Capobianco, M., Dette, H.H., Lechuga, A., Spanhoff, R., Stive, M.J.F., 2002. A summary of European experience with shore nourishment. Coastal Engineering 47, 237-264.

Hanson, H., Brampton, A., Capobianco, M., Dette, H.H., Hamm, L., Laustrup C., Lechuga, A., Spanhoff, A.R., 2002. Beach nourishment projects, practices, and objectives an European overview. Coastal Engineering 47, 81-111.

Hurlbert, S.J., 1984. Pseudoreplication and the design of ecological field experiments. Ecological Monographs 54, 187-211.

Kingsford, M.J., Battershill, C.N. 1998. Procedures for establishing a study, in: Kingsford, M.J., Battershill, C.N. (Eds), Studying temperate marine environments, a handbook for ecologists. Canterbury University Press, New Zealand, pp. 29-48.

Lohrer, A.M., Hewitt, J.E., Thrush, S.F., 2006. Assessing far-field effects of terrigenous sediment loading in the coastal marine environment. Marine Ecological Progress Series $315,13-18$.

Longstaff, B.J., Dennison, W.C., 1999. Seagrass survival during pulsed turbidity events: the effects of light deprivation on the seagrasses Halodule pinifolia and Halophila ovalis. Aquatic Botany 65, 105-121.

Luczak, C., Janquin, M.A., Kupka, A., 1997. Simple standard procedure for the routine determination of organic matter in marine sediment. Hydrobiologia 345, 87-94. 
Malmer, A., Grip, H., 1994. Converting tropical rainforest to forest plantation in Sabah, Malaysia. Part II. Effects on nutrient dynamics and net losses in stream water. Hydrological Process 8, 195-209.

Manzanera, M.; Pérez, M.; Romero, J. 1998. Seagrass mortality due to oversedimentation: an experimental approach. Journal of Coastal Conservation, 4: 6770.

McFarland, V.A, Peddicord, R.K., 1980. Lethality of a suspended clay to a diverse selection of marine and estuarine macrofauna. Reviews of Environmental Contamination and Toxicology 9, 733-741.

Miller, D.C., Muir, C.L., Hauser, O.A., 2002. Detrimental effects of sedimentation on marine benthos: what can be learned from natural processes and rates? Ecological Engineering 19, 211-232.

Molenaar, H., Barthélémy, D., Reffye, P., Meisnez, A., Mialet, I., 2000. Modelling and growth patterns of Posidonia oceanica. Aquatic Botany 66, 85-99.

Neverauskas, V.P., 1987. Monitoring seagrass beds around a sewage outfall in South Australia. Marine Pollution Bulletin 18, 158-164.

Onuf, C.P., 1994. Seagrass dredging and light in Laguna Madre, Texas, U.S.A. Estuarine Coastal and Shelf Science 39, 75-91.

Pergent, G., 1990. Lepidochronological analyses of the seagrass Posidonia oceanica (L.) Delile: a standardized approach. Aquatic Botany 37, 39-54.

Peterson, Ch.H., Hickerson, D.H.M., Johnson, G.G. 2000. Shot-term consequences of nourishment and bulldozing on the dominant large invertebrates of a sandy beach. Journal of Coastal Research 16, 368-378. 
Peterson, Ch.H., Bishop, M.J., Johnson, G.A., D`Anna, L.M., Manning, L.M., 2006. Exploiting beach filling as an unaffordable experiment: Benthic intertidal impacts propagating upwards to shorebirds. Journal of Experimental Marine Biology and Ecology 338, 205-221.

Ruíz, J.M., Perez, M., Romero, J., 2001. Effects of fish farm loadings on seagrass (Posidonia oceanica) distribution, growth and photosynthesis. Marine Pollution Bulletin 42, 749-760.

Ruíz, J.M., Romero, J., 2001. Effects of in situ experimental shading on the Mediterranean seagrass Posidonia oceanica. Marine Ecological Progress Series 215, 107-120.

Ruíz, J.M., Romero, J., 2003. Effects of disturbances caused by coastal constructions on spatial structure, growth dynamics and photosynthesis of the seagrass Posidonia oceanica. Marine Pollution Bulletin 46, 1523-1533.

Rumbold, D.G., Davis, P.W., Perretta, C., 2001. Estimating the effect of beach nourishment on Caretta caretta (Loggershead sea turtle) nesting. Restoration Ecology 9, 304-310.

Sand Jensen, K., Borum, J., 1991. Interactions among phytoplankton, periphyton and macrophytes in temperate freshwaters and stuaries. Aquatic Botany 41, 137-175.

Speybroeck, J., Bonte, D., Courtens, W., Gheskiere, T., Grootaert, P., Maelfait, J.P., Mathys, M., Provoost, S., Sabbe, K., Stienen, E., Lancker, V., Vinck, M., Degraer, S., 2006. Beach nourishment: an ecologically sound coastal defence alternative? A review. Aquatic Conservation 16, 419-435.

Terrados, J., Duarte, C.M., 2000. Experimental evidence of reduced particle resuspension within a seagrass (Posidonia oceanica L.) meadow. Journal of Experimental Marine Biology and Ecology 243, 45-53. 
Terrados, J., Borum, J., 2004. Why are seagrasses important? Goods and services provided by seagrass meadows, in: Borum, J., Duarte, C.M., Greeve, T.M. (Eds.), European seagrasses: an introduction to monitoring and management., the M\&MS project, pp.8-10. Available at: http://www.seagrasses.org

Touchette, B.W., Burkholder, J.A., 2000. Overview of the physiological ecology of carbon metabolism in seagrasses. Journal of Experimental Marine Biology and Ecology 250, 169-205.

Waters, T.F. 1995. Sediment in streams: sources, biological effects and control, in: American Fisheries Society Monograph 7. American Fisheries Society, Bethesda, Md, pp 251.

Underwood, A.J., 1992. Beyond BACI: the detection of environmental impacts on populations in the real, but variable, world. Journal of Experimental Marine Biology and Ecology 161, 145-178.

Underwood, A.J., 1993. The mechanics of spatially replicated sampling programmes to detect environment impacts in a variable world. Australian Journal of Ecology 18, 99116.

Underwood, A.J. 1994. On beyond BACI: sampling designs that might reliably detect environmental disturbances. Ecological Applications 4, 3-15.

Yemm, E.W., Willis, A.J., 1954. The estimation of carbohydrates in plant extracts by anthrone. Biochemistry 55, 508-514. 
Figure 1. Study area. Location of beach replenishment area, impacted (I) and control sites (C1, C2, C3, C4) along northern shore of Alicante coast. Shaded area indicates the P.oceanica meadows spread.

Figure 2. Average of 1) silt-clay fraction $( \pm \mathrm{SE}, \mathrm{n}=2)$ and 2$)$ organic matter fraction $( \pm \mathrm{SE}, \mathrm{n}=2)$ of sediment dumped on beach at three different times of replenishment project (July 2005, November 2005 and July 2006).

Figure 3. Average of 1) sediment height $( \pm \operatorname{SE}, n=12), 2)$ silt-clay fraction $( \pm S E, n=2), 3)$ and organic matter fraction $( \pm \mathrm{SE}, \mathrm{n}=2)$ before and after dumping at impacted and controls locations. 4) Average of silt-clay deposition rate $( \pm \mathrm{SE}, \mathrm{n}=2)$ after dumping. Mean with different letter is statistically different at $\mathrm{p}<0.01$.

Figure 4. Average of light availability in the study period $( \pm S E, n=14)$ before and after beach replenishment at impacted and controls locations.

Figure 5. Average of 1) shoot surface and 2) shoot biomass before and after dumping at impacted and controls locations. Control means with similar letter are not different before and after dumping. Impact means with different letters indicate statistically significant changes at $\mathrm{p}<0.01$ in relation to controls after dumping.

Figure 6. Average of 1) epiphyte biomass ( $\pm \mathrm{SE}, \mathrm{n}=10), 2$ ) cover of silt-clay attached to epiphytes $( \pm S E, n=10)$ and 3$)$ cover of filter feeding epiphytes $( \pm S E, n=10)$ before and after dumping at impacted and controls locations. Control means with similar letter are not different 
before and after dumping. Impact means with different letters indicate statistically significant changes at $\mathrm{p}<0.01$ in relation to controls after dumping.

Figure 7. 1) Starch reserves $( \pm \mathrm{SE}, \mathrm{n}=10)$ and soluble carbohydrates $( \pm \mathrm{SE}, \mathrm{n}=10)$, before and after dumping at impacted and controls locations. Control means with similar letter are not different before and after dumping. Impact means with different letters indicate statistically significant changes at $\mathrm{p}<0.01$ in relation to controls after dumping.

Figure 8. Average of horizontal rhizomes growth $( \pm \mathrm{SE}, \mathrm{n}=10)$ before and after dumping at impacted and controls locations. Horizontal growth before dumping was estimated by lepidochronology method, whereas after dumping it was estimated by direct method (labelling of horizontal rhizomes). Mean with different letter is statistically different at $\mathrm{p}<0.05$. 
Fig.1

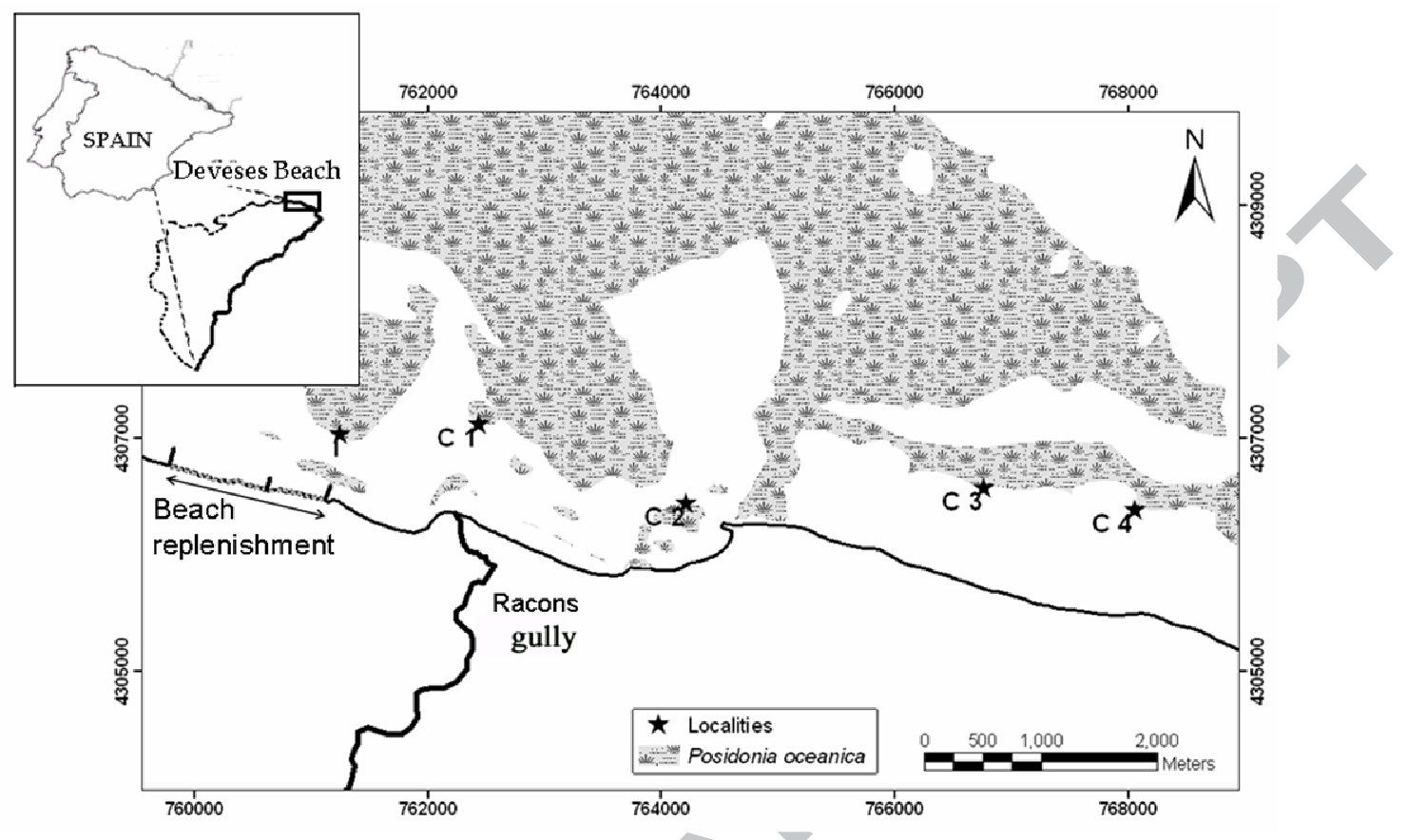




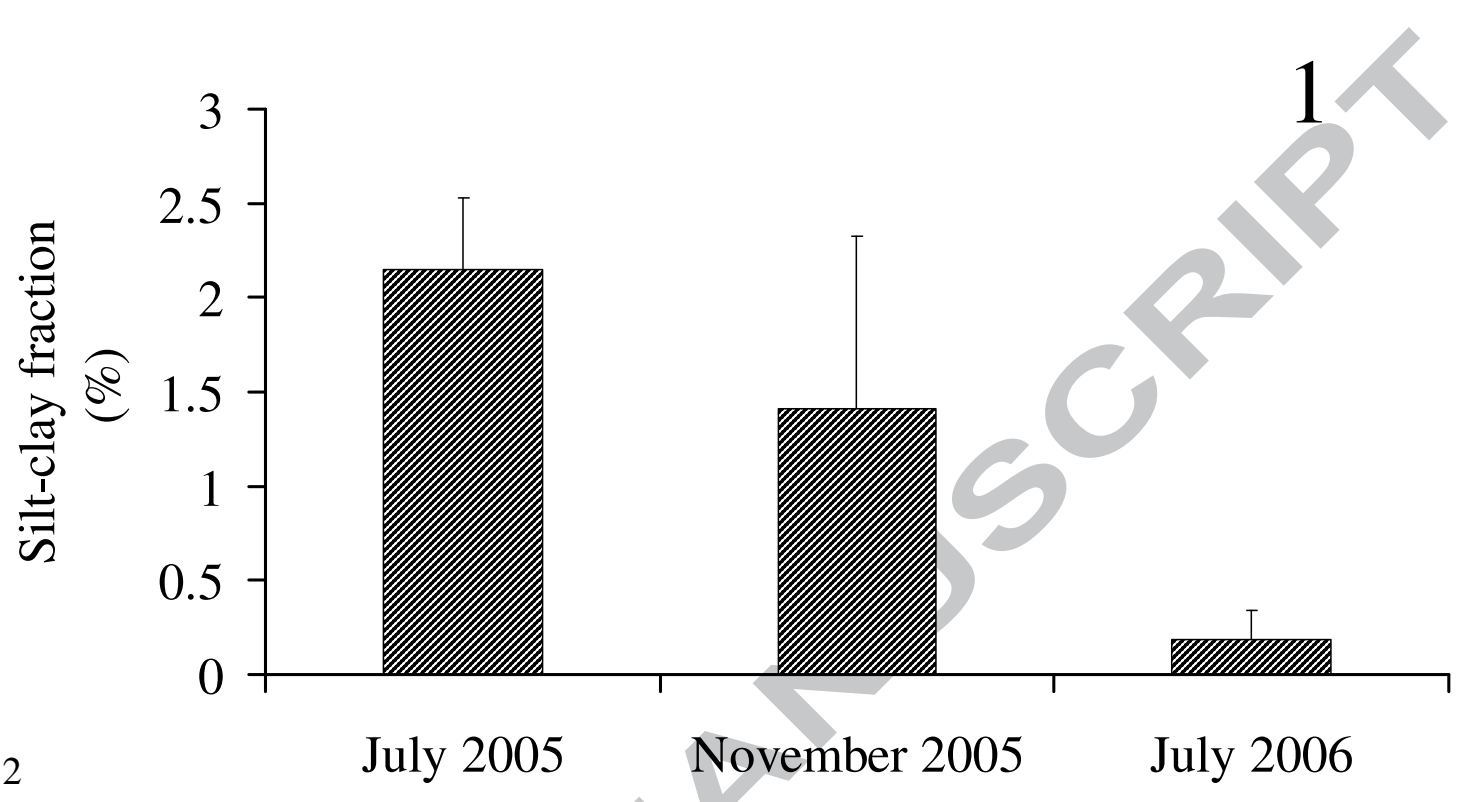

Fig.2

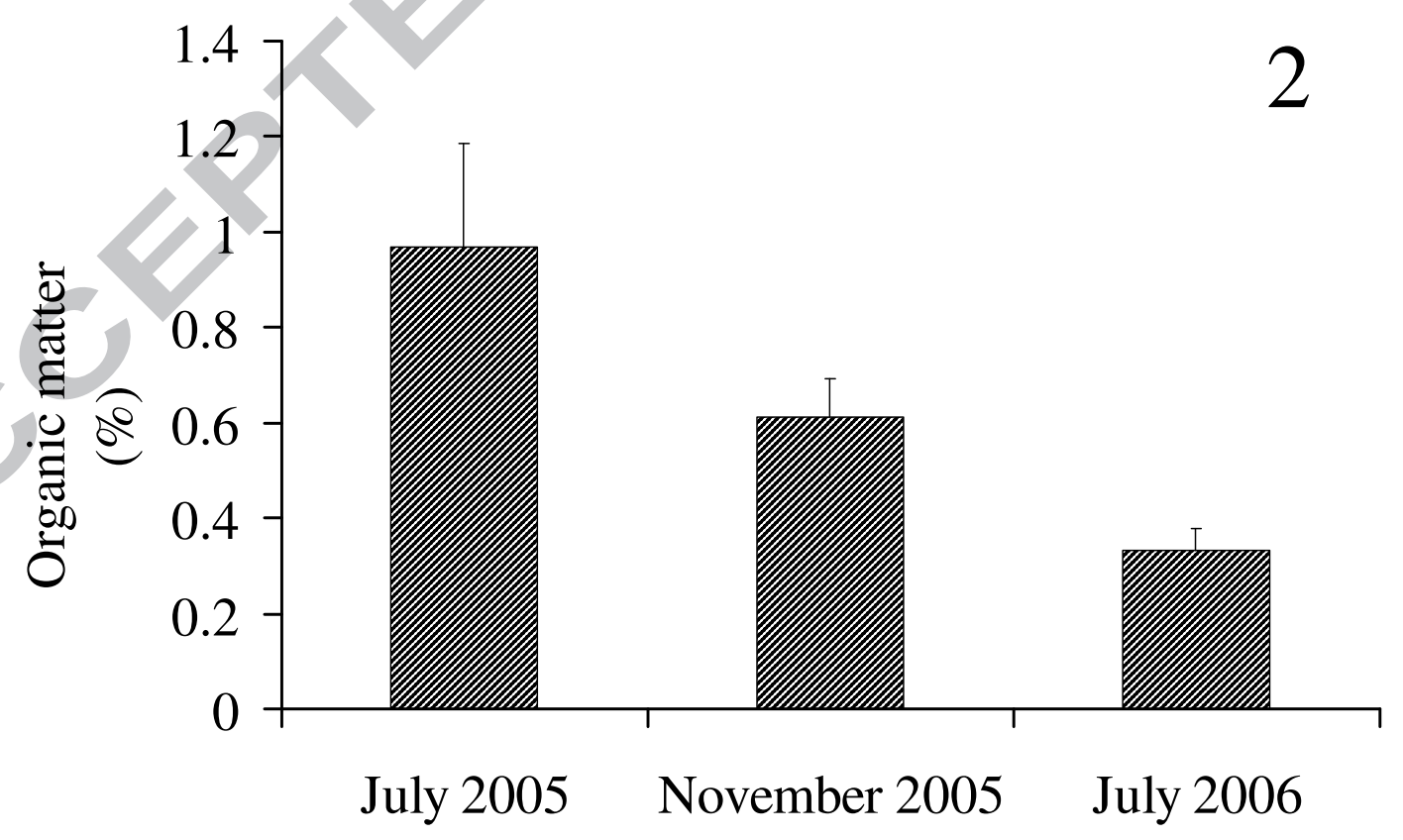


Fig.3
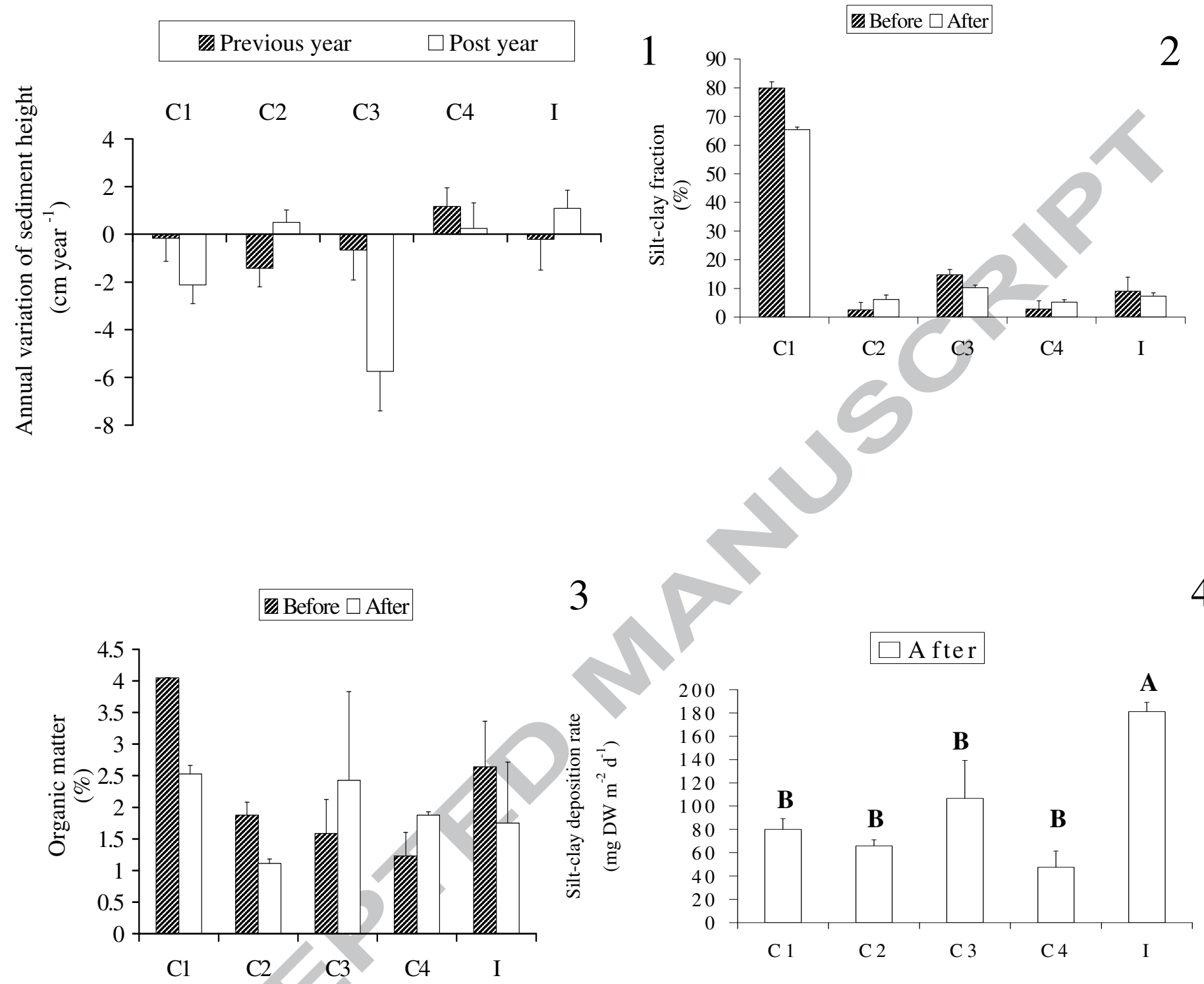
Fig.4

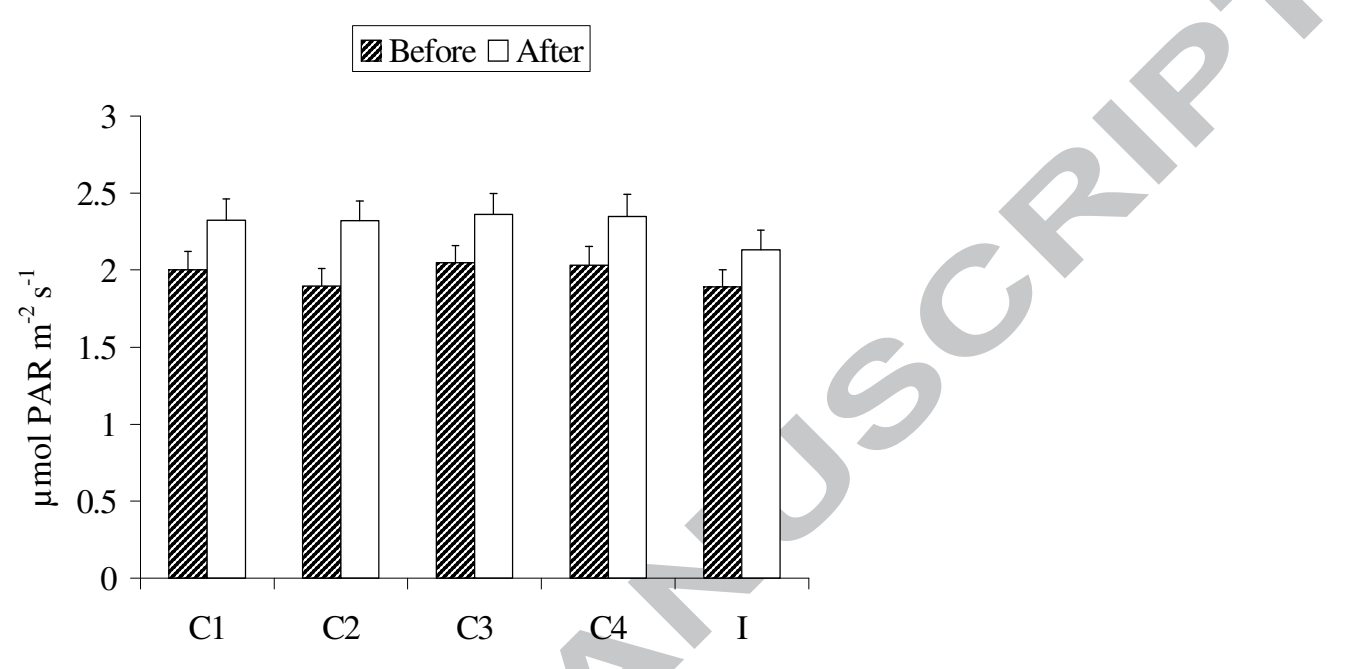


Fig.5
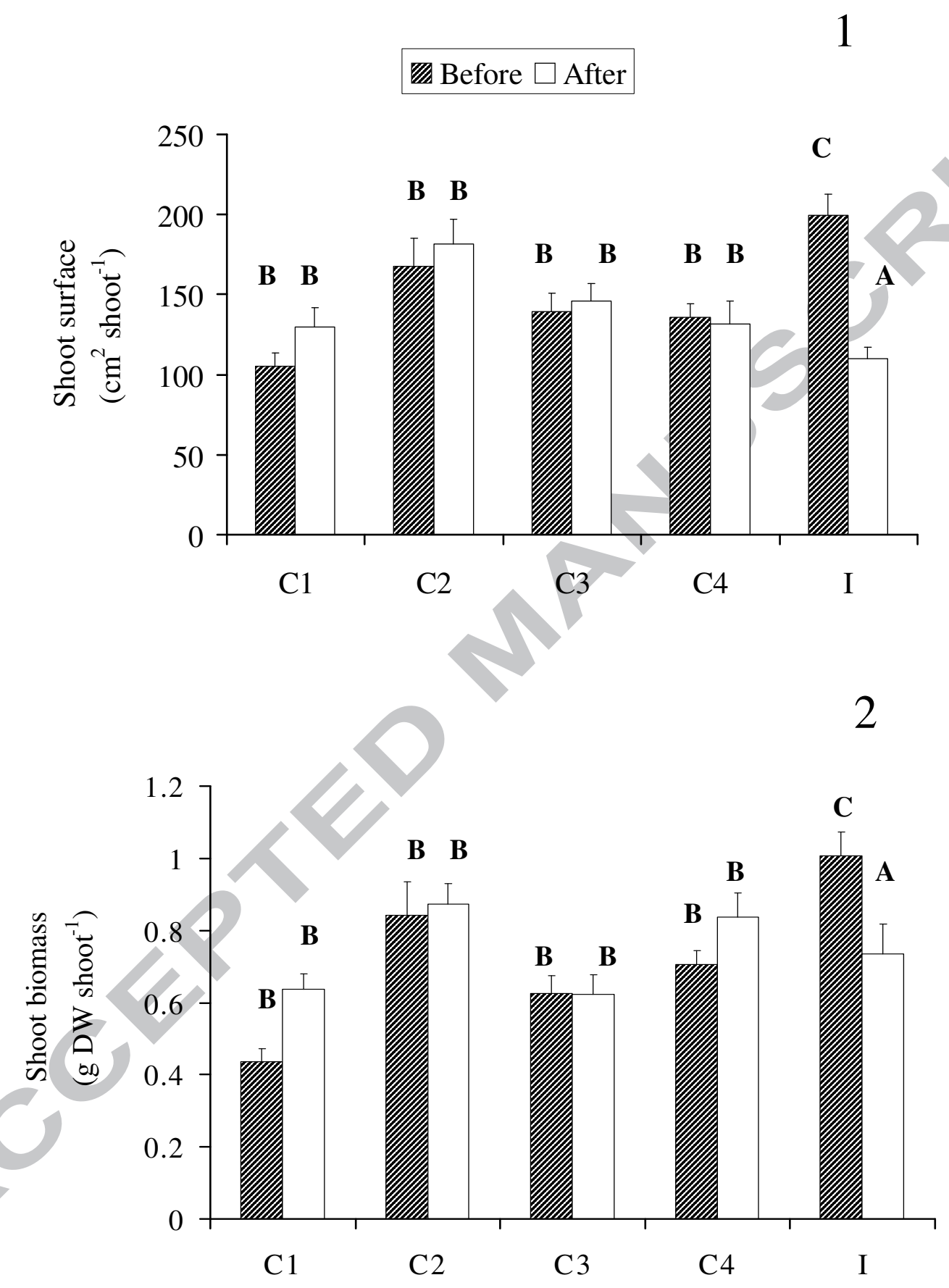
Fig.6
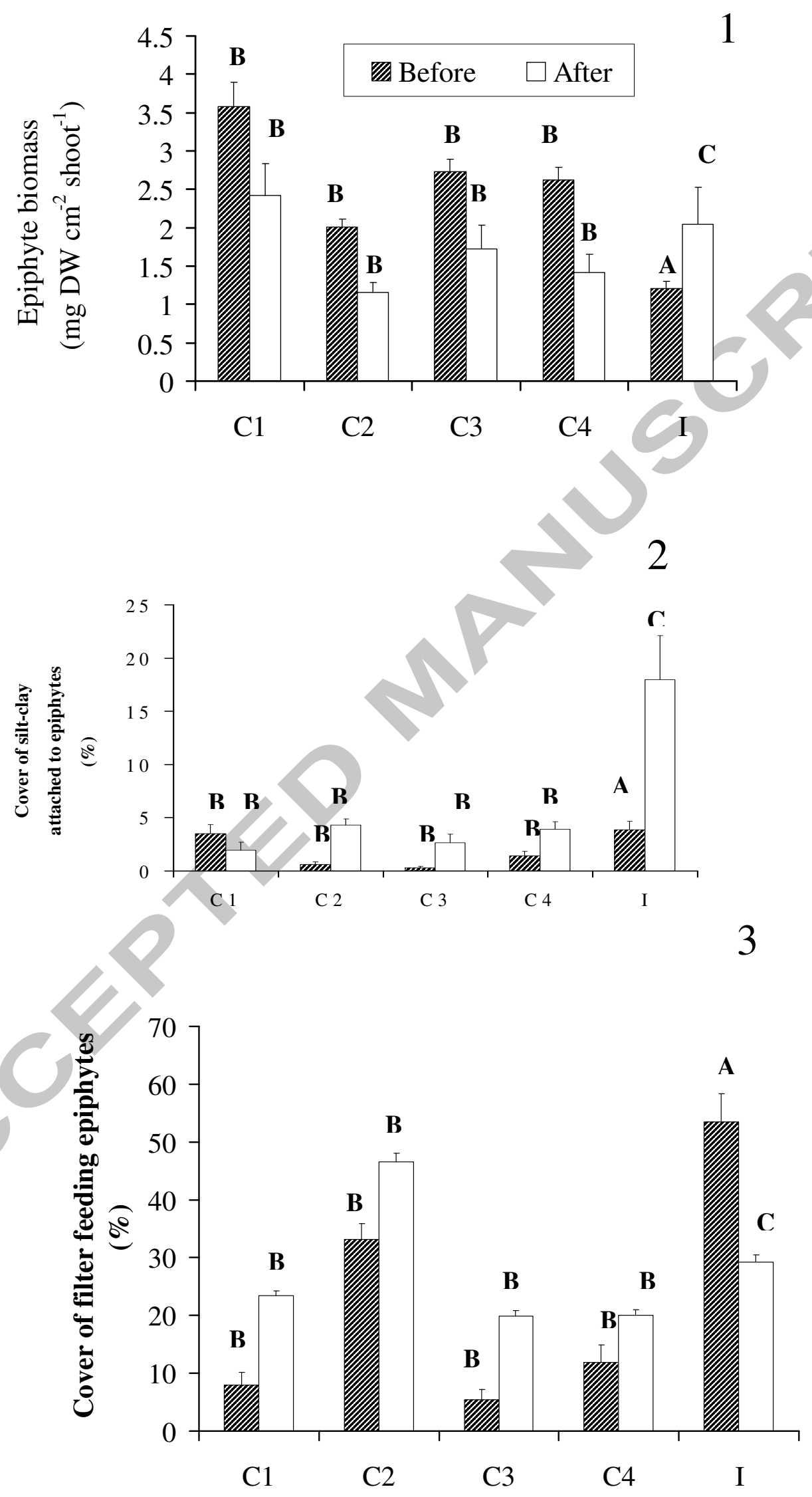
Fig.7
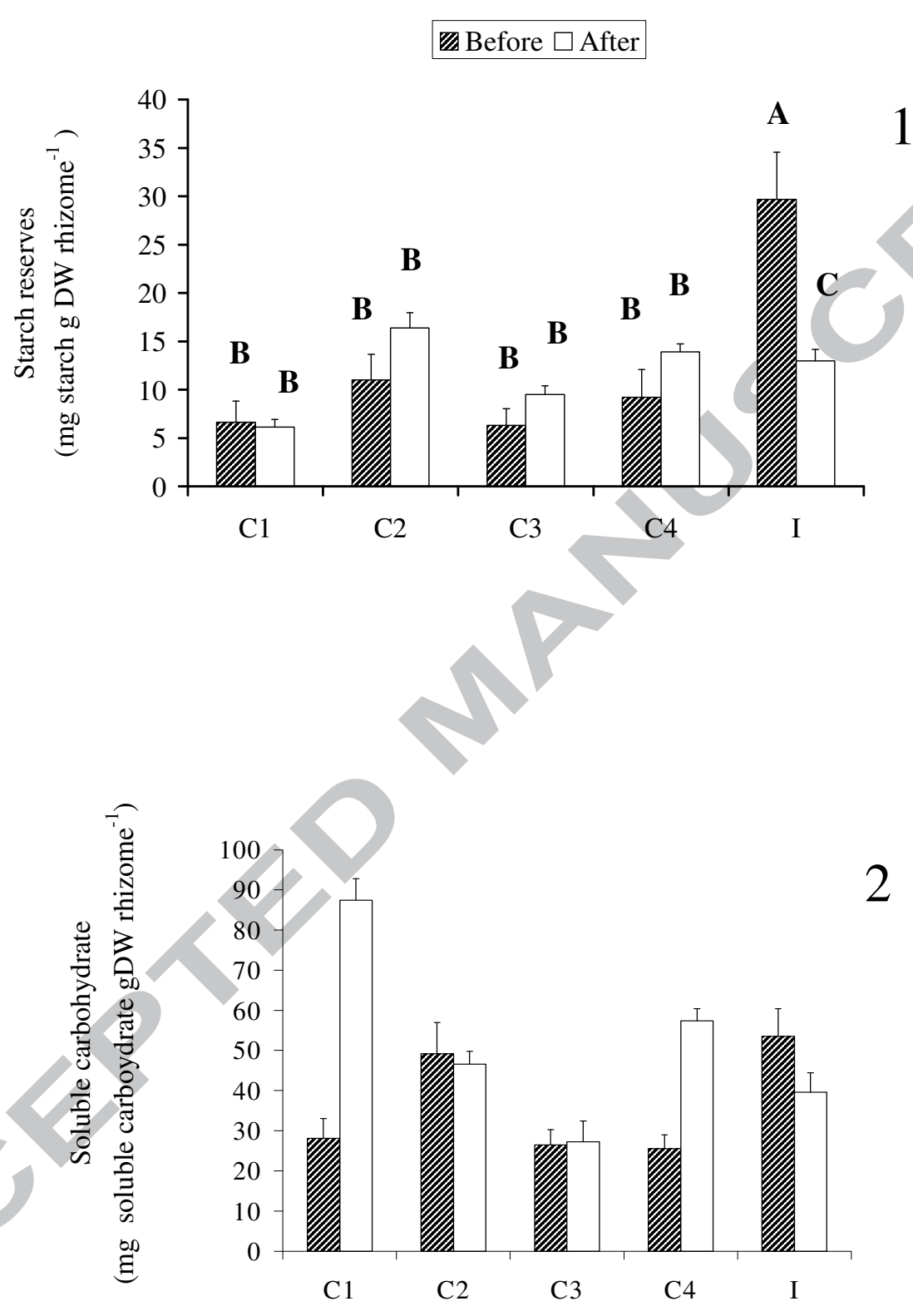
Fig.8

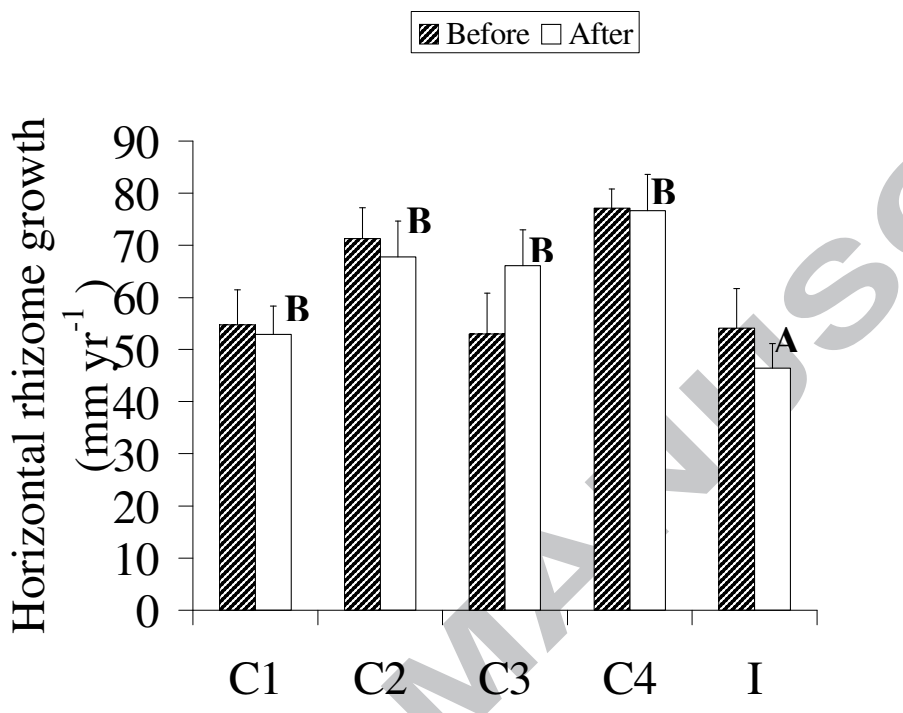

